\title{
Understanding the Forest Conservation Society actions "Tengger" ethnic Based Local Wisdom "Sesanti Panca Setya" in East Java - the Republic of Indonesia
}

\author{
$1^{\text {st }}$ Sumarmi \\ Faculty of Social Sciences \\ Universitas Negeri Malang \\ Indonesia \\ sumarmi.fis@um.ac.id
}

\begin{abstract}
National Park Bromo-Tengger-Semeru the "Tengger" ethnic inhabited by people. The Tengger ethnic majority of subsistence farmers around the protected forest area. This study aims to understand the Tengger ethnic community in conserving the forests based on local wisdom "Sesanti Panca Setya" or "sesanti five faithful". Environmental research sites in the Tengger community in the village Ngadas, Poncokusumo, Malang. This study used a qualitative method using a knife constructivist analysis. The data obtained by field observation and in-depth interviews with farmers, herbalists, and the village head Ngadas. Data were analyzed using triangulation techniques. The results showed that people Tengger ethnic in the act of conserving forests is closely related to the tradition of "sesanti panca setya" i.e: loyal culture (setya budaya), loyal discourse (setya wacana), promise faithfully (setya semya), loyal like (setya laksana), dan loyal partners (setya mitra). The findings of this research has a unique, different and complementary to previous research. The uniqueness of it is shown that the philosophy of "sesanti panca setya" turned out to be implemented by the Tengger community in managing and conserving forests. Forest conservation efforts done because it is very meaningful to support the continuity of farming communities Tengger ethnic itself.
\end{abstract}

Keywords: Tengger ethnic, local wisdom "sesanti panca setya", and forest conservation

\section{INTRODUCTION}

This research is motivated by the deteriorating environmental governance. Worsening environmental arrangement was due to population pressure, environmental carrying capacity, economic growth, and the development of science and technology tend to be environmentally friendly. Although in public life is no attempt to regulate population growth, but in fact there is a condition in which the population growth exceeds the carrying capacity of the environment. Problem of the deteriorating environment is perceived by people in developing countries, including in Indonesia, particularly the Tengger ethnic communities in East Java.

The majority of Tengger ethnic communities are farmers in the outskirts of the forest. Tengger ethnic farming area it is in a protected forest area "Bromo Tengger Semeru National Park" in East Java the Republic of Indonesia. Protected forest area is characterized by rugged topography, volcanic mountain areas, highland areas, and tropical forests. Some plant species found in Bromo Tengger Semeru National Park, among others: jamuju, pine, mountain pine, eidelweis, various orchids and grass species typical of mountain areas.

Tengger ethnic community activities in utilizing forest areas for economic improvement in general living in groups in the hills approaching agricultural land. They lived off the land in a field, with rain-fed irrigation. At first, the majority of them grow maize as a staple food, but it's been changed. In the dry season they grow vegetables such as potatoes, cabbage, onions, and carrots as a cash crop. At the end of the rainy season they grow maize as a staple food reserves. Tengger ethnic community farming systems undergo a change from subsistence to commercial farming system. This causes a change in the employment system, from system to system splice wage. Wage system is usually required by farmers whose land area.

Since the reign of Majapahit, the rate of population growth in Tengger ethnic community has been slow, but with the economic system change, population growth in the region is also growing rapidly becoming the commercial economy. The economy is changing with the commercial crops are widely cultivated. Tengger ethnic community economic changes caused by several things: (1) Increasing the accessibility of the area that allows workers entering the region. Even today many ethnic communities Tengger open services business (rental horses, Rental Home Stay and Jeep Hardtop as transportation, and kiosk). This is done since Mount Bromo opened as a tourist attraction; (2) The labor requirements increased due to agricultural systems that have been turned into commercial; (3) The farmers whose land is narrow becoming increasingly squeezed economically, so that they use the forest as an extension of agricultural land.

Darusman [1] and Awang [2] mentions forest communities must be considered because they: (1) is an integral part of the forest ecosystem, (2) is entitled to justice for marginalized, (3) as much as $20 \%-30 \%$ is still below the poverty line. Moreover, according to Brown and Sunderlin as also noted by Fauzi [3] and Fauzi [4] states that there are about 48.8 million 
people in Indonesia live in state forest area, 10.2 million people in poor condition, and 6 million people lives highly dependent on forest resources[5].

Facts show that the forms of interaction between society and the forest can be classified into three groups based on motivation and interests. First, people whose interaction with the forest only driven by economic factors. This group into the forest due to poverty. Second, community groups whose interaction with the forest driven by economic and environmental motivations. This group has the ability cultivation of forest conservation. Third, people who have been living in and around the forest in a very long period of his life dependent on the forest[6].

If they use the forests still pay attention to local wisdom and capacity of the environment, the forest will still be maintained continuity. However, population pressure is increasing, it is not uncommon local wisdom in everyday life can be lost. Furthermore, they destroy the forest to make ends meet. In the life of ethnic communities Tengger different conditions, they consistently preserve existing forests around his farm. It was shown that the agricultural technology used Tengger ethnic society it leads to forest conservation efforts[6].

Tengger ethnic uniqueness such as the focus of this research study. Therefore, the purpose of the research are: (1) Understanding the community's understanding of ethnic Tengger in an effort to preserve forests in "Bromo Tengger Semeru National Park" based on local wisdom "Sesanti Panca Setya" includes: (1) Setya budaya means obedient, diligent, independent, (2) Setya wacana means faithful to the words, (3) Setya semya means faithful to the promise, (4) Setya laksana means obedient, "tuhu", obedient, and (5) Setya mitra means loyal.

\section{RESEARCH METHODS}

This study was designed with qualitative methods using "knives analysis" konstruksionistik[7]. The location study performed in Tengger mountain region, particularly in the village of Ngadas, Poncokusumo, Malang, East Java. Ngadas village is a village that became the center settlement Tengger ethnic communities. Data obtained by the technique of documentation, observation, and in-depth interviews to assess and understand the actions of the Tengger in the forest preserve traditions associated with local wisdom "sesanti panca setya" or "sesanti five faithful". The informants include the village head, "dukun" (shaman) or "elders", and farmers around the forest in the village Ngadas. This study aims to determine the understanding Tengger ethnic communities about forest conservation efforts they did to the existence of "Bromo Tengger Semeru National Park". Data analysis was carried out simultaneously by using interactive techniques as recommended by Miles and Huberman (1995) and checking the validity of the data was done by using triangulation.

\section{RESULTS AND DISCUSSION}

\section{A. Results}

Tengger ethnic traditional houses are usually made of wooden poles and the walls and the roof was made and split bamboo. Once the home of such materials are difficult to obtain, today's society has changed the habit of using a roof of corrugated iron, board, or tile. Traditional house form usually found the halls. The centers are a kind of "divan" placed in front of the house. In the room of the house provided the furnace hearth (fireplace or "perapen") made and stone or cement. This fireplace length approximately $1 / 4$ of the length of the room available. Near the fireplace there is a short seat made of wood (dingklik = Javanese) in length and about half of the entire room. If a guest is received and seated in this area indicates that the guest is received with respect. Besides being used for body warmers for the occupants of the house, the fireplace is also used for drying corn or other food ingredients that require preservation and placed on "paga". "Paga" is a drying of foodstuffs placed on "perapen". Near space "perapen" are usually found in kitchen appliances and mortar (set pestle rice and corn).

Among some indigenous ceremonies, ceremonies "Kasada" is an example of the most famous traditional ceremony. The ceremony is to commemorate the sacrifice of a son Raden Kusuma, Jaka Seger, and the Lara Anteng. Kasada ceremony was conducted by the Tengger ethnic communities to ask for salvation and blessing. The ceremony is held on 14 to 16 months Kasada (one of the names in a matter of Javanese calendar month) or the full moon. The ceremony is held annually. The language used is the Tengger ethnic of ancient Javanese language. They use two levels, namely: (1) "ngoko" language as the language of everyday against his neighbor, and (2) karma to communicate with older people or parents are respected. In the Tengger ethnic communities there are differences of caste, in the sense that they are equal. Tengger ethnic communities in doing farm still perform the rituals associated with local customs[8].

Tengger ethnic communities have the perception that the natural environment must be maintained and must not be tampered with. Likewise, the flora and fauna to be preserved. They diligently to plant seasonal crops leeks, cabbage, potatoes, and corn. Tengger ethnic farmland classified as dry land, so that irrigation systems or irrigation depends on rain water and or wait for the supply of another village.

Soil fertility in agricultural areas strongly linked to ethnic Tengger volcanic ash released by Mount Bromo. Thus, the Tengger people do not consider the eruption of Mount Bromo as a disaster, so that when the eruption nothing evacuate because they believe it will not harm them. However, when the rainy season frequent landslides. If the landslides occurred on the main road, they will immediately contact the District government.

In order to meet the needs of people's daily life should Tengger farming. The farming activities carried out in the area around and inside the forest. Therefore, the emergence of community-based forest use policies and development of agricultural technologies with a system of forest conservation. 
In the late needs agricultural land utilize the forest area is increasing. As a result, the rough topography in the area which had become a place for the community farming Tengger (Yuliati, 2014). This leads to agricultural activities such as land forestry areas increasingly are critically endangered. It used to be very observant community to prey consisted of 12 prey: Bhaga, Ansu, Ariyama, Mitra, Waruna, Savitri, Dhatri, Wiwaswat, Twashtri, Pusha, Indra, and Whisnu (Suyono, 2009) to carry out agricultural activities in the field. But the rules of this prey is no longer strictly followed by ethnic Tengger, because of the ever increasing needs of the citizens. However, until now the environmental sustainability of forest management in the region are still well preserved. This is because one of them still implement Tengger community traditions or customs "sesanti five faithful".

Understanding Tengger ethnic communities in an effort to preserve forests in "Bromo Tengger Semeru National Park" based on local wisdom "Sesanti Panca Setia" as follows:

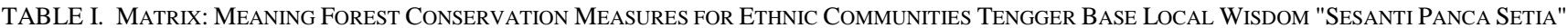

\begin{tabular}{|c|c|c|c|c|}
\hline No & Informant & Information obtained & Meaning action found & Themes found \\
\hline 1 & Ngatimin & $\begin{array}{l}\text { Based on what I understand people in the village Ngadas, are } \\
\text { not allowed and do not dare to plant or land in the area } \\
\text { "Bromo Tengger Semeru National Park". Society may only } \\
\text { take the firewood is dry from. The public is not allowed } \\
\text { taking medicinal plants and farming on the sidelines of the } \\
\text { moor. During this time the Departement of Perhutani do } \\
\text { counseling once a month to assess the activities carried out } \\
\text { society, so that people do not disturb forest conservation. }\end{array}$ & $\begin{array}{l}\text {-Propagates formal rules on forest } \\
\text { maintenance } \\
\text {-Propagates forest maintenance } \\
\text { required due to the existence of forests } \\
\text {-Tradisi Farming around the forest and } \\
\text { maintaining its sustainability } \\
\text {-Education Care routine can sensitize } \\
\text { the forest environment }\end{array}$ & $\begin{array}{l}\text { - Setya laksana } \\
\text {-Setya wacana and setya } \\
\text { semya } \\
\text {-Setya budaya } \\
\text {-Setya laksana and Setya } \\
\text { mitra }\end{array}$ \\
\hline 2 & Sarinoto & $\begin{array}{l}\text { Based on what I understand people in the village Ngadas, are } \\
\text { not allowed and do not dare to plant or land in the area } \\
\text { "Bromo Tengger Semeru National Park". Society may only } \\
\text { take the firewood is dry from. The public is not allowed } \\
\text { taking medicinal plants and farming on the sidelines of the } \\
\text { moor. The Departement of "Bromo Tengger Semeru National } \\
\text { Park" counseling once a month to assess the activities of } \\
\text { forest conservation. }\end{array}$ & $\begin{array}{l}\text {-Act according to formal rules on } \\
\text { forest maintenance } \\
\text {-Preserve forests because forests } \\
\text { required } \\
\text {-Pengelola Forests make forest } \\
\text { conservation pay attention to tradition } \\
\text { awake } \\
\text {-Tradisi Farming around the forest and } \\
\text { maintaining its sustainability }\end{array}$ & $\begin{array}{l}\text { - Setya laksana } \\
\text {-Setya wacana and setya } \\
\text { semya } \\
\text {-Setya Semya } \\
\text {-Setya budaya }\end{array}$ \\
\hline 3 & Mujianto & $\begin{array}{l}\text { Tengger people understand, that the Tengger people in the } \\
\text { village Ngadas already know that the village is in a national } \\
\text { park, but not all people know about it. Community efforts to } \\
\text { maintain forest conservation by not cutting down trees } \\
\text { carelessly. People really adhere to the rules. The } \\
\text { consequences are caused when people violate existing } \\
\text { regulations were fined } 45 \text { cement bags }\end{array}$ & $\begin{array}{l}\text { - Awareness of ethnic perch are loyal } \\
\text { and obedient to the rules } \\
\text { - Faithful maintain various crops in the } \\
\text { forest because the forest where } \\
\text { necessary } \\
\text { - Given punishment for people who } \\
\text { violate the rules }\end{array}$ & $\begin{array}{l}\text {-Setya mitra and setya } \\
\text { semya } \\
\text {-Setya wacana and setya } \\
\text { semya } \\
\text {-Setya wacana }\end{array}$ \\
\hline 4 & Mistono & $\begin{array}{l}\text { Based on what I know once people who do not have land, } \\
\text { they can open and manage agricultural land in forest areas } \\
\text { with a rental system. Currently the rules are applied "Bromo } \\
\text { Tengger Semeru National Park", the public is not allowed to } \\
\text { clear land. Society may only utilize wood in the forest that } \\
\text { has fallen as firewood. I think even though people already } \\
\text { know that the village entrance area Ngadas "Bromo Tengger } \\
\text { Semeru National Park", but they do not know division } \\
\text { zoning-zoning in the management of national parks. }\end{array}$ & $\begin{array}{l}\text {-Complying with the formal rules of } \\
\text { forest maintenance } \\
\text {-Faithful maintain various crops in the } \\
\text { forest because the forest where } \\
\text { necessary } \\
\text {-Zoning fields yet, but obedient people } \\
\text { in farming }\end{array}$ & $\begin{array}{l}\text { - Setya laksana } \\
\text {-Setya wacana dan setya } \\
\text { semya } \\
\text {-Setya mitra }\end{array}$ \\
\hline 5 & Suyak & $\begin{array}{l}\text { I know people never cooperate with the Department of } \\
\text { Forestry in the conservation of agricultural land bordering the } \\
\text { forest. Ngadas villages including the village of buffer. First } \\
\text { cooperative society to be cows, apple tree seedlings. Apples } \\
\text { are grown can live but could not bear fruit. The first cow } \\
\text { rolling, approximately } 5 \text { mice for people who do not have } \\
\text { land. after a large scrollable when the cow has sold more shall } \\
\text { buy cattle again tillers. }\end{array}$ & $\begin{array}{l}\text { - People perched in partnership with } \\
\text { the Forest service to jointly preserve } \\
\text { the forest. } \\
\text { - Maintain cattle to increase the } \\
\text { carrying capacity of forest } \\
\text { conservation }\end{array}$ & $\begin{array}{l}\text {-Setya mitra } \\
\text {-Setya laksana and setya } \\
\text { budaya }\end{array}$ \\
\hline 6 & Senen & $\begin{array}{l}\text { Society cooperative with the "Bromo Tengger Semeru } \\
\text { National Park", which is the program's name "green line". The } \\
\text { program was carried out by planting crops on land borders as } \\
\text { wide as } 10 \text { square meters. Wood sidelines should be planted } \\
\text { vegetables. If the wood is grown no longer allowed to grow } \\
\text { vegetables there. For the cleared forest land, trees planted } \\
\text { acacia and pine trees. In my opinion the acacia trees and fast- } \\
\text { growing trees rapidly depleted due to rotting, the longest } 10 \\
\text { years. People today should not undermine national park, so } \\
\text { that the more green forests continues. } \\
\text { Tengger communities have the perception that the natural } \\
\text { environment must be maintained and must not be tampered } \\
\text { with. Likewise, the flora and fauna to be preserved. }\end{array}$ & $\begin{array}{l}\text { - People perched in partnership with } \\
\text { the Forest service to jointly preserve } \\
\text { the forest. } \\
\text { - People do reforestation of denuded } \\
\text { land } \\
\text { - Faithful maintain various crops in the } \\
\text { forest because the forest where } \\
\text { necessary } \\
\text { - Preserving the continuity of forest for } \\
\text { farming }\end{array}$ & $\begin{array}{l}\text {-Setya laksana and setya } \\
\text { budaya } \\
\text {-Setya laksana } \\
\text {-Setya wacana and setya } \\
\text { semya } \\
\text {-Setya budaya }\end{array}$ \\
\hline
\end{tabular}


Teachings and philosophy of life in the form of Tengger ethnic "sesanti panca setya" covering culture, setya discourse, setya semya, setya like, and setya partners are still implemented in everyday life. Various forms of the implementation as shown in the matrix above. Some forms of the implementation of the "sesanti panca setya" to the farming life around and in the woods shown Tengger people's behavior as follows: Complying with the formal rules concerning the maintenance of the forest; Faithfully preserving forests because forests where necessary; Farming traditions around forest and maintaining its sustainability; Routine care counseling can sensitize the forest environment; Tengger ethnic awareness that solidarity and abide by the rules; Tengger community partner with the Forest Service to jointly preserve the forest; Maintaining cattle to improve forest sustainability and carrying capacity; Preserving the continuity of forest for farming.

On the basis of understanding Tengger community life in the forest preserve and conservation fields into place their farm, this research finding new proposition as follows:

"Sesanti Panca Setya" is "sesanti" which has been entrenched in people's lives Ethnic Tengger. "Sesanti panca setya" is closely related to the management and conservation of protected forests in the Tengger Mountains. Forest sustainability is closely related to the continuity of farming Tengger ethnic society

\section{B. Discussion}

According Tengger relations philosophy, in accordance with the teachings of living in Tengger ethnic communities as contained in the doctrine of attitudes with "sesanti panca setya". Philosophy of life "sesanti panca setya" is the most widely associated with environmental management in daily life. On the basis of "sesanti" that harmony in society could look like at the time of mutual cooperation in conducting farming activities, build houses and repair roads. The public aware of the hygiene and preserving the environment. If they look dirty environment, for example, they immediately clean up without any orders.

Tengger ethnic community forest conservation to preserve the environment and boost the economy of the community. Tengger houses built on the land, which as far as possible selected on a flat area, close to the water, or if he had been ground can be made terraces, and far and wind interference. The houses are located close together or gather in a place that can be entered and the various departments connected by a narrow path between one village to another. Construction of a house always begins with salvation, similarly, if a building has been completed held salvation again. At each building that is being done there is always the "sesajen" or "offerings", hung on poles, in the form of food, rhombus, lepet, plantain and others. The building houses the vast Tengger usually because generally inhabited by several families.

Excessive exploitation of natural resources will have a negative impact on the survival of ecosystems. One issue that received much attention that increasing economic growth will result in the destruction of nature, such as deforestation.
Damage was caused mainly by increased population pressure also because faced with two choices are quite difficult to be separated. Two options that include maintaining the function of forests as natural buffer or as production forest. If as production forests, it is useful as a contributor to the economy of the community and the state. To solve the dilemma of treebased farming system, known as forest conservation is done as a policy option. Such a thing can be done by Tengger ethnic communities by applying local wisdom traditions or "sesanti panca setya" in forest conservation efforts.

This is in line with the opinion of Sunaryo (2003) in which over forest land to agricultural land cause many problems such as decreased soil fertility, erosion, extinction of flora and fauna, floods, droughts and even global environmental change. This problem gets worse over time in line with the increase in the total area of forest land to other businesses. Forest conservation is one of the land management system that may be offered to address the problems that arise as a result of the land above and at the same time to address the problem of improving the community's economy. However, this research proves that these problems can be overcome by utilizing the local wisdom that has long been prevailing in public life, including "sesanti five faithful" in forest conservation efforts at the Tengger community life.

Reality shows that the implementation of forest conservation in the Tengger people are not easily implemented, without involving local wisdom "sesanti five faithful" and extension to implement. For example, forests of pine and fir underneath vegetables planted over time many stands of pine trees and yew reduced, without them understanding "setya semya" means faithful to the promise. It was almost the same as the results Muspida (2008), with stages with Pattern of "Pecan" (pohon Kemiri) Forest conservation as follows: land preparation, plant maintenance "pecan" and seasonal crops. Harvesting that threatens the sustainability and conservation of forest conservation hazelnut in Maros is the tendency of farmers to convert forests into other commodities hazelnut. It was due to limited public access to the rejuvenation of the old "pecan" trees.

To improve the trees reduced the need for increased community participation based on local wisdom, such as the results of research conducted Marupaey in Central Maluku. Because community participation include: (a) optimizing utilization patterns and land use by the community of farmer in the village forests and state forests; (b) increased community participation in the conservation and preservation of village forests and state forests; and (c) the strengthening of the legal and customary institutions that Sasi and Kewang (Maruapey, 2010).

Research results Mulyadi (2011) proved that the motivation to preserve the environment and environmentally sound behavior of each farmer affected by local wisdom and locus of control. Both exogenous variables are also indirect effect on environmentally friendly behavior through motivation of farmers to preserve the environment. These findings indicate that local knowledge variables, locus of control and motivation to preserve the environment is a factor that determines the realization of environmentally sound 
behavior of farmers. The attitude of farmers whose fields are increasingly concerned about the forest environment in Tengger ethnic stronger when they understand the local wisdom "sesanti five faithful" they have for a long time. This sort of thing was also supported by the results of previous research noted that the people who are around the forest often in oppressed conditions, so they need to be empowered (Sidu, 2010).

Human relations according to Tengger ethnic philosophy, in accordance with the teachings and philosophy of life that exist in the Tengger community itself. Teachings and philosophy of life that they named "sesanti panca setya", namely: (1) Setya budaya means obedient, diligent, independent, (2) Setya wacana means faithful to the words, (3) Setya semya means faithful to the promise, (4) Setya laksana means obedient, tuhu, obedient, and (5) Setya mitra means loyal partners. It was, as has been revealed by the findings Sidu (2009) in research on guidelines Tengger community life. However, the findings of this study complements the previous findings. Where the philosophy of "sesanti panca setya" are understood to be implemented by the Tengger people in everyday life, especially in managing forest sustainability that is meaningful to the continuity of their farming. Thus, Tengger ethnic communities in farming not only think for the moment, but also to think about the future.

Forms of local wisdom Tengger ethnic communities in conserving the forest guided by farming traditions, beliefs, religions, and cultures. One of the local wisdom that give positive consequences on the environment is "sesanti panca setya". Religion professed by the majority is Hindu Tengger community. According to Hinduism who deem that pure and "Danyang" is something sacred. For Tengger ethnic communities, the ceremony is one manifestation of public gratitude to God. There are many traditional ceremonies in Tengger ethnic communities who have diverse goals. Some goals ceremonies, among others requesting a blessing, distanced catastrophe, an expression of gratitude for the gift given by God

\section{CONCLUSION}

Ethnic Tengger in the act of conserving forests is closely related to the tradition of "sesanti panca setya" or "sesanti five faithful". Where the doctrine of living attitude maintaining forest environment Tengger people always guided by five fidelity, namely: (1) Setya budaya means obedient, diligent, independent, (2) Setya wacana means faithful to the words, (3) Setya semya means faithful to the promise, (4) Setya laksana means obedient, tuhu, obedient, and (5) Setya mitra means loyal partners. The findings of this research complements and strengthens the findings of previous research. However, the uniqueness of this research demonstrated the existence of that philosophy "sesanti five faithful" turned out to be implemented by the Tengger ethnic communities to manage and conserve forests. Forest conservation efforts done because it is very meaningful to support agricultural business continuity Tengger ethnic society itself.

\section{REFERENCES}

[1] D. Darusman, "Adaptation of forest Preservation Society in Small Islands," JMHT, vol. 15, no. 3, pp. 130-136, 2008.

[2] S. Awang, Social Deconstruction Forestry, Reposition Public and Environmental Justice. Yogyakarta: Bigraf Publishing, 2007.

[3] H. Fauzi, "Community Economic Profile Social Activities in and Around the Forest Zone in Banjar Regency," J. Trop. For. Borneo, vol. 7, no. 28, pp. 63-82, 2009.

[4] H. Fauzi, "Community Empowerment in Rural Areas in Forest Resources Management (A Case Study of Production Forest conservation Banjar South Kalimantan)," Brawijaya, 2014

[5] S. Bahri, "High Deforestation, Government Failure Guard Presidential Instruction No. 10/2011," 2014. [Online]. Available: Dakwatuna com. [Accessed: 03-Jul-2014].

[6] K. Hairiah, Simulation Model For the Forest Preservation System. Bogor, 2002.

[7] A. Fatchan, Qualitative Research Methods: Construction Approach and Phenomenology. Malang: UM-Press, 2013.

[8] L. C. Koopelman, R., Asia Facific Agroforestry. Bangkok: FAO, 1996 